\title{
Prevalence of sickle cell anemia, $\beta$-thalassemia and glucose-6-phosphate dehydrogenase deficiency among the tribal population residing in the Aravali hills of Sirohi region of Rajasthan state
}

\author{
S.S. Mohanty ", S. Parihar, R.K. Huda, G.S. Toteja, A.K. Sharma \\ National Institute for Implementation Research on Non-Communicable Diseases (Formerly Known As Desert Medicine Research Centre, Jodhpur), New Pali Road, \\ Jodhpur, 342005, Rajasthan, India
}

\section{A R T I C L E I N F O}

\section{Keywords:}

$\beta$-Thalassemia

Glucose-6-phospahate dehydrogenase

Sickle cell disorder

Tribe

\begin{abstract}
A B S T R A C T
Objective: The tribal population in India constitutes nearly $8.6 \%$ of its total population. Haemoglobinopathies is widely prevalent among the tribal population than the non-tribal communities in India. Due to its wide prevalence, haemoglobinopathies is a major cause of concern for the tribal health research in India. The present study was under taken to investigate the spectrum of hemoglobinopathies, in particular sickle cell anemia (SCA), among the primitive tribal groups of India.

Methods: This is a cross sectional community based study and carried out in the Abu Road Block of Sirohi District. The study was conducted through medical camp at schools and villages. The screening of SCA, $\beta$-thalassemia and G6PD deficiency were carried out using solubility, NESTROFT and DPIP methods respectively. Confirmatory test for SCA and $\beta$-thalassemia was done by using CE-HPLC (Bio-Rad). The confirmatory test of G6PD deficiency was conducted through enzymatic assay.

Results: A total of 7167 tribal individuals were screened for SCA and out of which 610 individuals were found to be SCA positive with a prevalence of $8.51 \%$. The prevalence of $\beta$-thalassemia was recorded as $7.25 \%$. The prevalence of SCA was found to be higher in Garasia tribes and $\beta$-thalassemia prevalence was higher in the Bhil community. The prevalence of G6PD deficiency was found to be $2.88 \%$.

Conclusion: SCA, $\beta$-thalassemia and G6PD deficiency were prevalent among the tribal population of Rajasthan residing in the Aravali Hills of Sirohi. Mass screening and management of SCA is essential to ensure improve quality of life of affected tribal individuals.
\end{abstract}

\section{Introduction}

The tribal population in India primarily lives in rural and inaccessible areas and is among the most vulnerable and marginalized section of the society. These groups have poor health and developmental indicators as compared to non-tribal groups (Tribal Health in India). ${ }^{1}$ According to census 2011, tribal population of India is $8.6 \%$ of the total population. The tribal population in India is scattered across 30 states and union territories. They possess diverse cultural and life practices and are a heterogenous group. There are more than 705 different ethnic tribal groups in India and of these 12 present in Rajasthan. In Rajasthan, they constitute $13.6 \%$ of total population i.e. 9.23 million. $^{2}$ Further, because of their isolated existence and endogamy over centuries, different tribal populations have distinctive genetic identities.

Burden of anemia weighs heavily on the National Health resources as a consequence effective interventions are required. Haemoglobinopathies is one of the major causes of non-iron anemia. Haemoglobinopathies particularly haemoglobin S, D, E, $\beta$-thalassaemia and enzyme deficiency of glucose-6-phospahte dehydrogenase (G6PD) are important challenges for tribal populations in India. The HbS, $\mathrm{HbE}, \beta$-thalassaemia and G6PD genes are variably distributed across various tribal populations of India. Sickle cell disease is one of the most widely recognized monogenic disorder across the Miditerranean, Africa, South East Asia and India all around with an autosomal recessive inheritance. Sickle cell disorder results due to a mutation in position 6 of the $\beta$-globin chain of hemoglobin $(\mathrm{Hb})$ resulting in replacement of glutamic acid with valine

; G6PD, glucose-6-phospahte dehydrogenase; Hb, Hemoglobin; SCA, Sickle Cell Anemia.

* Corresponding author.

E-mail address: mohanty.s@dmrcjodhpur.nic.in (S.S. Mohanty). 
residue.

$\beta$-Thalassemia is the other common autosomal recessive disorder among tribal communities worldwide. Different molecular mechanisms, most of which are base substitutions or small deletions or insertions of one or two nucleotides in the $\beta$-globin gene are responsible for $\beta$-thalassemia. Moreover, it has been found that $\beta$-thalassemia mutations are relatively population specific, i.e. each ethnic group has its own set of common mutants.

Estimation of G6PD deficiency and its prevalence in the malaria endemic areas inhabited by tribal population is essential for the effective management of clinical cases due hemolysis associated with Chloroquine and Primaquine in G6PD deficient individuals. Although the prevalence of G6PD deficiency in some of the tribal populations in India is known, however it's prevalence in tribal communities in Rajasthan is not identified.

The dominant tribal groups Garasia, Bhils, Meena and others have an unmixed gene pool than the other nontribal populations; this high degree of inbreeding among these tribal groups may result in a relatively high prevalence of genetically inherited blood disorders such as sickle cell disease, resulting in anemia. Therefore, the present study was undertaken to investigate the spectrum of hemoglobinopathies, in tribal communities in Rajasthan.

\section{Methods}

\subsection{Study sites}

The study was conducted in the Abu Road Block of Sirohi District. As per the census of 2011, total population of Abu Road Block is 2.24 lacs of which 1.04 lac is tribal. Bhil, Garasia, Damor and Meena are the principal tribes living in this area. Screening was conducted in health camps organized for the purpose in schools and in villages having predominantly tribal population. Villagers were informed in advance about the camps.

\subsection{Study design}

This is a cross sectional community based survey. The ASHA, Angwadi worker and ANM were told before three days of the schedule of the survey. All the household in the village were informed before one day of survey. The medical officer along with the team camp in the school or nearby Community Centre for the survey.

\subsection{Screening test for sickle cell disease}

Solubility test was used to detect presence of sickle hemoglobin (HbS). This method is a primarily used large scale screening in short time. HbS has decreased solubility in the deoxygenated state in a hypotonic buffer which produces turbidity. ${ }^{3}$ Forty micro-liters of each blood sample was mixed with $2 \mathrm{ml}$ of stock solution containing $0.02 \%$ sodium dithionate in a polycarbonate vial and left to stand at room temperature for $5 \mathrm{~min}$. The samples were examined using light against the background of black lines. The results were interpreted as positive when the black lines were not visible. A known negative control (AA) and a known positive control (HbSS) were performed daily before initiation of the screening. Two ml venous blood sample was collected in EDTA containing vacutainer from sickle hemoglobin positive individuals for confirmation of genetic status. The blood samples in vacutainer were transported to bio-chemistry laboratory of the NIIR-NCD, Jodhpur and stored at $4{ }^{\circ} \mathrm{C}$ till analysis.

\subsection{NESTROFT test for $\beta$-thalassemia}

NESTROFT is a single tube qualitative osmotic fragility test used for preliminary screening for $\beta$-thalassemia based on the limit of hypotonicity which the red cells can withstand. ${ }^{4}$ Two millilitre of the buffer solution was taken in polycarbonate vial and a drop of blood was added to each tube and they were left undisturbed for $30 \mathrm{~min}$ at room temperature. Polycarbonate vials were then shaken and held against a white paper on which a thin black line was drawn. If the line was clearly visible through the contents of the tube, it was marked as negative for the test and if the line was not clearly visible, the test was considered positive. A positive test indicates lowered red cell osmotic fragility, suggestive of $\beta$-thalassemia trait.

\subsection{Confirmatory test for the sickle cell anemia and $\beta$-thalassemia}

Cation Exchange High Performance Liquid Chromatography (CEHPLC) was performed on BioRad variant II using $\beta$-thal short program. $\mathrm{HbA} 2$ more than $4.0 \%$ was taken as cutoff for the detection of $\beta$-thalassemia trait.

\subsection{DPIP test for G6PD deficiency}

Screening for G6PD deficiency was done by dichlorophenolindophenol (DPIP) dye de-colorization method. ${ }^{5}$ Twenty microliter of the whole blood was added to $1 \mathrm{ml}$ distilled water and mixed to lyse the cells. Then $0.5 \mathrm{ml}$ of the reagent mixture was added, topped with mineral oil and incubated at $37{ }^{\circ} \mathrm{C}$, the time taken for de-colorization from blue to a red yellow end point was noted. The blood of normal subjects decolorizes within 5-20 min. Female heterozygotes for G6PD deficiency may show either normal or an intermediate de-colorization time i.e. 20-80 min. If the sample did not decolorized even after $80 \mathrm{~min}$ of test initiation, it was considered as G6PD deficient.

\subsection{Newborn screening for sickle cell disease}

Umbilical cord blood was collected for new born screening and subjected to CE-HPLC. Cord blood was collected after obtaining informed and understood consent from either of the parents.

\subsection{Ethics committee}

The study was approved by the Institutional Ethics Committee of the National Institute for Implementation Research on Non-Communicable Diseases (Formerly known as Desert Medicine Research Centre, Jodhpur).

\section{Results}

Students of 63 schools and residents of 17 villages were included inthe screening for sickle cell anemia (Supplementary Table 1). A total of 7167 tribal individuals were tested for sickle cell anemia test and out of which 610 individuals $(8.51 \%)$ were found to be sickle cell positive. Five hundred thirty four individuals consented for confirmatory test by HPLC (Bio-Rad Variant-II). Of these 476 (7.69\%) showed presence of HbS in heterozygous state (Hb-AS) and $39(0.63 \%)$ showed homozygosity for HbS (Hb-SS) (Table 1).

Comparison of prevalence of the sickle cell trait between different

Table 1

The prevalence of the Sickle Cell disease (\%) among the tribes residing in the in Abu Road block of Rajasthan.

\begin{tabular}{llllll}
\hline $\begin{array}{l}\text { Name } \\
\text { of the } \\
\text { Tribe }\end{array}$ & $\begin{array}{l}\text { Individuals } \\
\text { Screened }\end{array}$ & $\begin{array}{l}\text { Prevalence } \\
\text { of SCD in \% } \\
\text { (n) }\end{array}$ & $\begin{array}{l}\text { Prevalence } \\
\text { of AS in \% } \\
\text { (n) }\end{array}$ & $\begin{array}{l}\text { Prevalence } \\
\text { of SS in \% } \\
\text { (n) }\end{array}$ & $\begin{array}{l}\text { Refused } \\
\text { to give } \\
\text { blood } \\
\text { samples } \\
\%(n)\end{array}$ \\
\hline Garasia & 6182 & $9.54(590)$ & $7.70(476)$ & $0.63(39)$ & $1.21(75)$ \\
Bhil & 663 & $2.41(15)$ & $2.26(15)$ & 0.00 & $0.15(1)$ \\
Other & 322 & $1.24(4)$ & $1.24(4)$ & 0.00 & 0.00 \\
Total & 7167 & $8.51(610)$ & $6.91(495)$ & $0.54(39)$ & $1.06(76)$ \\
\hline
\end{tabular}


ethnic groups tested, it was observed that the highest prevalence (9.54\%) was recorded among the Garasias. The prevalence of trait was found to be $2.41 \%$ among the Bhils (Table 1 ). No positivity was observed among Meena Tribe. It may be noted that only 14 individuals from Meena community were tested.

A total of 118 newborn babies were also screened for sickle cell disorder by HPLC. Among them, 21 newborns were showed presence of sickle cell trait (AS) and remaining 97 newborns were normal (AA). The prevalence of sickle cell trait among newborns in the study area was recorded to be $17.8 \%$ (Fig. 1). Among these newborns, $22 \%$ (n-17) and $10 \%(\mathrm{n}-2)$ prevalence was reported in Garasia and Bhil tribes respectively.

In all 952 individuals were screened for $\beta$-thalassemia and of them 69 (7.25\%) were found to be $\beta$-thalassemia positive (Table 2). The comparative prevalence of $\beta$-thalassemia between Bhils and Garasias showed that the Bhils had higher prevalence (14.2\%) Vs Garasias (7.44\%) (Table 2).

Similarly, blood samples of 465 individuals were screened for G6PD deficiency. Thirteen individuals (2.79\%) were found to be deficient for G6PD enzyme (Table 3). When the prevalence of G6PD deficiency was compared among the tribes, highest prevalence was recorded among the Garasias (Table-3).

\section{Discussions}

The first report of sickle cell anaemia in India was by reported by Lehman and Cutbushin $1952^{6}$ among the tribal populations in the Nilgiri hills in south India. Dunlop and Mazumder ${ }^{7}$ reported the sickle haemoglobin among the tea garden workers of Assam who were tribal migrants from states of Bihar and Odisha. Thereafter, many clusters of the tribal populations have been screened and frequency of the sickle cell gene has been estimated and recorded. ${ }^{8}$ These results show high prevalence of sickle haemoglobin among the socio-economically disadvantaged ethnic groups i.e., the scheduled tribes. The prevalence of sickle cell carriers among different tribal groups varied from 1 to $40 \%{ }^{9} \mathrm{HbS}$ is reported mainly in Maharashtra, Madhya Pradesh, Andhra Pradesh, Orissa, and Gujarat and to a lesser magnitude in Tamil Nadu, Karnataka, Kerala and Uttar Pradesh. The presence of sickle cell anemia is rare in Bihar, West Bengal, North-Eastern States, Punjab, Haryana, Himachal Pradesh, Rajasthan and Jammu \& Kashmir. ${ }^{10}$ We earlier observed 5.8\% prevalence among tribes in Rajasthan (Mohanty et al.). ${ }^{11}$ The present study reports for the first time, the prevalence of the sickle cell in the region. Choubisa et al. ${ }^{12}$ earlier have reported a $6.25 \%$ prevalence of sickle cell disorder among the Garasia tribes in Udaipur Disrict but here we have reported a prevalence of $13.8 \%$ among the Garasia tribes. The sample size of the study population of Choubisa et al. ${ }^{12}$ was comparatively small to the current study (368 Vs 7167).

It is estimated that each year, 10,000 children with thalassemia major are born in India, which comprises $10 \%$ of the total number in the world. ${ }^{13}$ In contrast to the global frequency of $1.5 \%$, the average carriers

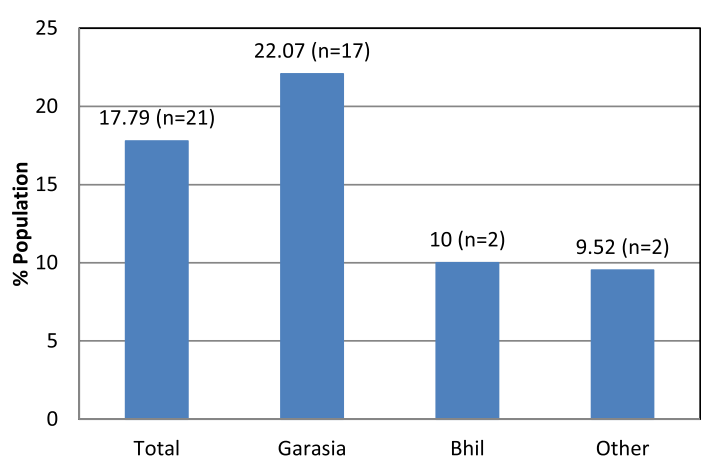

Fig. 1. Tribe wise prevalence (\%) of sickle cell disorder (AS) among newborns in Abu Road Block of Sirohi District.
Table 2

Prevalence of beta-thalassemia among different tribal population of Abu Road block of Sirohi District.

\begin{tabular}{lll}
\hline $\begin{array}{l}\text { Name of the } \\
\text { tribe } \mathrm{s}\end{array}$ & $\begin{array}{l}\text { Number of individual } \\
\text { screened }\end{array}$ & $\begin{array}{l}\text { Prevalence of beta thalassemia in } \\
\%(\mathrm{n})\end{array}$ \\
\hline Garasia & 900 & $7.44(67)$ \\
Bhil & 7 & $14.29(1)$ \\
Other & 45 & $2.22(1)$ \\
All & 952 & $7.25(69)$ \\
\hline
\end{tabular}

Table 3

Tribe wise prevalence of g6pd deficiency among the tribal population of Abu Road block of Sirohi District.

\begin{tabular}{lll}
\hline $\begin{array}{l}\text { Name of the } \\
\text { tribe } \mathrm{s}\end{array}$ & $\begin{array}{l}\text { Number of individuals } \\
\text { screened }\end{array}$ & $\begin{array}{l}\text { Prevalence of G6PD deficiency in } \\
\%(\mathrm{n})\end{array}$ \\
\hline Garasia & 416 & $2.88(12)$ \\
Bhil & 7 & $0.00(0)$ \\
Other & 42 & $2.38(1)$ \\
All & 465 & $2.8(13)$ \\
\hline
\end{tabular}

of $\beta$-thalassaemia trait ( $\beta \mathrm{TT})$ in India comprise $3.3 \%$ of the population. $^{14,15}$

The overall gene frequency of $\beta$ TT in Mumbai and Delhi were $2.68 \%$ and $5.47 \%$ respectively. Majority of the children with $\beta$ TT from Mumbai were from Marathi (38.9\%) and Gujarati (25\%) speaking groups. Wherein, the gene frequency was $>5 \%$ in Bhatias, Khatris, Lohanas and Schedule Caste communities. ${ }^{16}$ When analyzed in Delhi population, highest incidence was observed in children of Punjabi origin (7.6\%). Jain et al. ${ }^{17}$ recorded $6.75 \% \beta$-thalasemia in the students of the West Bengal, which is higher than the prevalence in Delhi and Mumbai. In Vadodora city of Gujarat, 2.5\% $\beta$-thalassemia cases were reported by Mohanty et al. ${ }^{18}$ In the present studies, prevalence of $\beta$ TT was $7.25 \%$.

Kumar et al. $(2016)^{19}$ reviewed the prevalence of glucose-6-phosphate dehydrogenase deficiency in India and reported high percentage of prevalence among the tribes of Odisha. Balgir et al. $(2004)^{20}$ reported $27.04 \%$ prevalence of G6PD deficiency in the Paraja tribes of Odisha and were highest among all. The prevalence of G6PD among the Garasia tribes $(2.88 \%)$ of Rajasthan is lower than that reported in the tribes of Odisha. Jain et al. $(1992)^{21}$ reported $1.8 \%$ prevalence of G6PD deficiency in the mixed population of Rajasthan.

World Health Organization recommends that carriers should be detected, counselled, improvement in curative services, prenatal diagnosis and education for community control of hereditary anaemias is essential for robust health economy. ${ }^{22}$ The earlier authors have suggested that intensive counseling of targeted population groups is more effective than all community counseling and is cost-effective and cost-efficient as well. ${ }^{23}$ The usefulness of community screening in the present study was tailor made to suit local communities in different geographical and socio-cultural situations. Low number of testing of individuals for $\beta$-thalassemia and G6PD deficiency may be considered a short fall of the present studies. Large scale screening for all 3 disorders is warranted for identifying the correct prevalence and disease burden.

\section{Conclusion}

The results of the study show a higher prevalence of sickle cell anemia in the Garasia tribal population in both adults and newborns. $\beta$-Thalassemia and G6PD deficiency are also found in the Garasia and Bhil tribes.

\section{CRediT authorship contribution statement}

SSM and GST conceived and designed the study. SSM, SKP and GST wrote the protocol. SSM, SKP, RKH and AKS generated and analyzed the 
data. AKS, SSM, RKH, and GST wrote the report, and all authors contributed to the drafts before submission.

\section{Funding}

The study was funded by Indian Council of Medical Research, New Delhi under the sub head of Tribal Sub-Plan.

\section{Declaration of competing interest}

We declare no competing interests.

\section{Acknowledgements}

Authors are thankful to Sh. B. S. Detha, IAS, Divisional Commissioner and Commissioner, Tribal Area Development Department, Udaipur for providing the support for the implementation of the study. The authors are also grateful to Sh. Pankj Mishra, Director, Swatch for giving us the opportunity to conduct the study in the MaaBadi Centres and Hostels of the Abu Road Block of Sirohi District. We thank all the teachers and coordinators of the MaaBadis, Schools and Hostels for their help in grouping the students for conducting the study. We thank all the Medical Officers and Paramedical staffs helping in clinical assessment, solubility test and $\mathrm{Hb}$ estimation in the study. We thank Sh. Rajinder Singh, St. Technical Assistant, Sh. Trilok Kumar, Laboratory Assistant and Sh. B. Manohar, Laboratory Assistant for their extensive support in the preparation of chemicals and demonstration during the training and screening work.

\section{Appendix A. Supplementary data}

Supplementary data to this article can be found online at https://doi. org/10.1016/j.cegh.2021.100916.

\section{References}

1 Report of the expert committee on Tribal Health, Ministry of Health and Family Welfare. Tribal Health in India: Bridging the Gap and a Roadmap for the Future. 2018: $1-56$.

2 Census of India. Office of the Registrar General \& Census Commissioner. India: Ministry of Home Affairs, Government of India; 2011. http://censusindia.gov.in.
3 Huntsman, et al. A rapid whole blood solubility test to differentiate sickle cell trait to sickle cell anamia. J. ClinicalPathol. 1970;23:781.

4 GorakshankarAC Colah R, Nadkarni A, Desai S. Evaluation of the single tube osmotic fragility test in detection of beta thalassemia trait. NMJI (Natl Med J India). 1990;3: 171-173.

5 Benstein RE. DPIP decolourisation test for G6PD deficiency. Nature. 1962;194:192.

6 Lehman H, Cutbush M. Sickle cell trait in southern India. Br Med J. 1952;1(4755): 404-405.

7 Dunlop KJ, Mazumber UK. The occurrence of sickle cell anemia among a group of tea garden labourers in Upper Assam. Indian Med Gaz. 1952;87:387-391.

8 Colah, R.B., Mukherjee, M. B., Martin, S., Ghosh, K. Sickle cell disease in tribal populations in India. Indian J Med Res 141, 509-515.

9 Bhatia HM, Rao VR. Genetic Atlas of Indian Tribes. Bombay: Institute of Immunohaematology (ICMR); 1987.

10 Sarnaik SA. Thalassaemia and related haemoglobinopathies. Indian J Pediatr. 2005; 72:319-324.

11 Mohanty SS, Purohit A, Anand PK, Huda RK, Sh. Assessment of Burden of Sickle Cell Trait and Disease Among Tribal Students of South Rajasthan. Submitted to Indian Journal of Medical Research; 2021.

12 Choubisa SL. Sickle cell haemoglobin, thalassaemia and G-6-PD enzyme deficiency genes in Garasiya tribe inhabited malaria endemic areas of Sirohi district, Rajasthan (India). J Comm Dis. 2009;41:13-18.

13 Varawalla NY, Old JM, Venkateshanz SR, Weatherall DJ. The spectrum of beta thalas-semia mutations on the Indian subcontinent the basis of prenatal diagnosis. $\mathrm{Br}$ J Hematol. 1991;78:242-247.

14 Edison ES, Shaji RV, Devi SG, et al. Analysis of beta globin mutations in the Indian population, presence of rare and novel mutations and region-wise heterogeneity. Clin Genet. 2008;73:331-337, 2008.

15 Cousens NE, Gaff CL, Metcalfe SA, Delatycki MB. Carrier screening for betathalassemia, are view of international practice. Eur J Hum Genet. 2010;18: 1077-1083.

16 Madan N, Sharma S, Sood SK, Colah R, Bhatia HM. Frequency of $\beta$-thalassemia trait and other hemoglobinopathies in northern and western India. Indian J Hum Genet. 2010;16:16-25.

17 Jain BB, Roy RN, Ghosh S, Ghosh T, Banerjee U, Bhattacharya SK. Screening for thalassemia and other hemoglobinopathies in a tertiary care hospital of West Bengal: implications for population screening. Indian J Publ Health. 2012;56:297-300.

18 Mohanty D, Colah RB, Gorakshakar AC, et al. Prevalence of b-thalassemia and other haemoglobinopathies in six cities in India: a Multicenter study. J Commun Genet. 2013;4:33-42.

19 Kumar P, Yadav U, Rai V. Prevalence of glucose-6-phosphate dehydrogenase deficiency in India: an updated meta-analysis. Egypt J Med Human Genet. 2016;17: 295-302.

20 Balgir RS, Dash B, Murmu B. Blood groups, hemoglobinopathy and G-6-PD deficiency: investigations among fifteen major scheduled tribes of Orissa, India. Anthropol. 2004;6:69-75.

21 Jain RCG-6PD. Deficiency in malaria endemic areas of Udaipur District in Rajasthan. J Assoc Phys India. 1992;40:662-663.

22 World Health Organization. Sickle cell anaemia. 59th World Health Assembly. https ://apps.who.int/gb/archive/pdf_files/WHA59/A59_9-en.pdf; 27 May 2006.

23 Sur D, Mukhopadhyay SP. Prevalence of thalassemia trait in the state of West Bengal. J Indian Med Assoc. 2006;104:11-15. 